\title{
М.В. Шашина
}

Національний технічний університет Украӥни «Київський політехнічний інститут імені Ігоря Сікорського», Україна

\section{ФОРМУВАННЯ ЄВРОПЕЙСЬКОЇ ІНСТИТУЦІОНАЛЬНОЇ МОДЕЛІ СТРУКТУРНОЇ МОДЕРНІЗАЦІЇ РЕГІОНАЛЬНОЇ ЕКОНОМІКИ}

В статті обтрунтовано сутність поняття «структурна модернізація регіональної економіки». Розкрито історичний процес формування інституціональної моделі структурної модернізації регіональної економіки в Свропі. Розкрито сутність принципів побудови європейської моделі структурної модернізації, а саме: лідерство та горизонтальна координація, вертикальна координація, участь зацікавлених сторін, очінка та огляд, визначення індикаторів і моніторинг. Визначено основні інститути, щуо сприяють структурній модернізації регіонів Свропи. Розраховано інтегральні коефіцієнти структурних зрушень в регіонах України у 2017 році та визначено регіони, які зазнали найбільших структурних змін. Окреслено основні причини структурних диспропориій в регіональній економічі України. Запропоновано формувати інституціональну модель структурної модернізаџї регіональної економіки Украйни на основі вертикальних інтегральних структур та інститутів сприяння малому підприємництву.

Ключові слова: структурна модернізація, регіональна політика, інституціональна модель, ЄС, структурні зрушення.

\section{Постановка проблеми}

В межах країн Євросоюзу було створено ефективну інституціональну модель забезпечення структурної регіональної модернізації економіки, що розповсюджується не тільки на всі ієрархічні рівні влади, а й на неурядові організації. Така система дозволяє реалізовувати принципи сталого розвитку найвіддаленіших регіонів, адже являється досить щільною та деталізованою.

Сучасні реалії регіонального розвитку регіонів України, їх диспропорція та асиметричність висувають проблему необхідності грунтовної структурної перебудови, реалізація якої неможлива без аналізу передових практик світу в реалізації економічних та структурних регіональних політик.

\section{Аналіз останніх досліджень і публікацій}

Дослідженню формування європейської інституціональної моделі структурної модернізації регіональної економіки в розрізі історичної еволюції присвячені праці Архипенко I. [1], Бородіної О. [2], Іжи М. [3] та Ціватого В [4]. В праці Марушевського Г. [5] окреслено основні принципи, на яких побудована дана модель.

Максимчук М. [6] та Прокопюк А. [7] вивчали питання адаптації європейського досвіду регіональної політики в реаліях України.

\section{Формулювання цілей статті (постановка завдання)}

Метою статті є дослідження практичних аспектів формування європейської інституціональної моделі регіональної структурної модернізації економіки.

\section{Виклад основного матеріалу}

Економічний характер модернізації визначається прогресом суспільства та зміною його матеріальної бази, тобто технічної, технологічної та економічної основ. Останнім часом модернізація отримала широке наукове визнання як сучасний інститут вирішення структурних та технологічних проблем економіки. Тому постає питання сутності структурної модернізації економіки.

Прокопюк А. дає таке визначення структурній модернізації: «зміни позитивного характеру, які призводять до інтенсивного зростання економіки за рахунок підвищення продуктивності, технологічності, інноваційності виробничих процесів та раціонального використання ресурсів. Результатом структурної модернізації економіки регіону має стати забезпечення його конкурентоспроможності як на національному, так і на світовому рівнях» [7].

Структурна модернізація регіональної економіки здійснюється в рамках регіональної політики, яка передбачає функціонування місцевих органів влади 3 метою забезпечення збалансованої структури економіки. Передусім, регіональна структурна політика 
повинна забезпечувати таку галузеву структуру, яка відповідає визначеним національним стратегічним цілям.

Формування сучасної інституціональної моделі структурної модернізації регіональної економіки в Європі пройшло чотири етапи [2]:

1. 1920-ті - 1970-ті - перші спроби реалізації регіональної політики в європейських державах. Основною спрямованістю політики виступає підтримка слаборозвинених територій та районів 3 не модернізованою промисловістю. В 1957 році закладаються основи формування європейської моделі регіонального розвитку, що окреслювалося в преамбулі Римських договорів (25.02.1957).

2. 1970-ті - 1980-ті - подолання соціальноекономічних диспропорцій в розвитку регіонів. Регіональна політика даного періоду спрямована не тільки на забезпечення розвитку слаборозвинених регіонів, а на підтримку всіх регіонів Європейської економічної спільноти як структурних елементів європейського господарства. Головним інструментом реалізації регіональної структурної політики виступає Європейський фонд регіонального розвитку. Важливо зазначити, що регіональні програми розвитку будувалися на принципах партнерства, субсидіарності, децентралізації, додатковості, концентрації та програмування, що було головною умовою забезпечення узгодженості інтересів між країнами-учасниками.

3. 1980-ті - початок XXI ст. - перехід до постіндустріальної системи та удосконалення регіональної політики. Основним поштовхом до кардинальних змін в регіональному управлінні стало підписання Європейської хартії місцевого самоврядування (15.10.1985), Єдиного європейського акту (17.02.1986), Маастрихтського договору (7.02.1992) та Амстердамського договору (2.10.1997). Регіональна політика спрямована на забезпечення конкурентоспроможності регіонів шляхом підвищення науково-освітнього потенціалу, інноваційної активності та місцевої ініціативи. Відтак, пріоритетами стратегії регіональної політики виступають економічне зростання, розвиток малого та середнього підприємництва, посилення інноваційної спроможності, розвиток відсталих територій на основі прогресивних механізмів.

4. Поч. XXI ст. - регіональна політика згуртування. Докорінна зміна підходу до управління регіональним розвитком, що грунтується на тісній вертикальній та горизонтальній інтеграції. На даному етапі спостерігається зростання ролі регіонів в глобальному економічному просторі, яка залежить від рівня їх конкурентоспроможності, а також міжрегіонального співробітництва. Ще одним важливим аспектом даного етапу є формування інноваційної політики, що об'єднала в собі функції наукової, промислової, соціальної та регіональної політик. Наразі основними інструментами реалізації регіональної політики виступають наступні: Європейський сільськогосподарський фонд (EAGGF), Європейський соціальний фонд (ESF), Свропейський фонд регіонального розвитку (ERDF), Фінансовий інструмент орієнтації рибальства (FIFG), Фонд згуртування (CF) та Структурні фонди (SF). Тенденції останніх років свідчать про скорочення обсягів вертикальної та галузевої державної допомоги, а також збільшення частки програм горизонтальної допомоги (до 90\%) [8].

Європейська інституціональна модель структурної модернізації регіональної економіки побудована на таких засадах [5]:

1. Лідерство та горизонтальна координація в управлінні регіональною політикою $С С$, що має галузевий характер. Структурна модернізація кожної окремої галузі здійснюється на основі узгодження між сукупністю наявних галузевих політик. Координація являється важливим аспектом забезпечення збалансованого розвитку регіонів, тому виконання даної функції, в основному, покладається на державні органи влади. Відтак, управління процесом структурної модернізації кожної галузі регіону підпорядковується національним стратегіям збалансованого розвитку.

2. Вертикальна координація, тобто взаємодія центральних, регіональних та місцевих органів влади в питаннях структурної модернізації регіональної економіки. Центральними органами влади визначаються стратегічні напрями та завдання, які деталізуються та контролюються на регіональному та місцевому рівнях. Варто зазначити, що розробка стратегічних напрямів здійснюється на основі таких підходів: управлінсько-плановий (на основі фахівців уряду, міністерств та відомств), відомчо-науковий (на основі робочих груп науковців та фахівців відомств), фахово-управлінський (розробляється відповідною інституцією сталого розвитку), партисипативний (залучення фахівців уряду, міністерств, відомств, а також представників громадськості) [9].

3. Участь зацікавлених сторін, що є основою ефективного управління модернізацією регіональних економік. Даний принцип реалізується через урядові та неурядові ради збалансованого розвитку. Так, в Ірландії, Німеччині, Фінляндії, Чехії та Швейцарії зацікавлені сторони являються учасниками національних урядових рад, в Бельгії, Португалії та Франції вони діють через неурядові консультативні національні ради зацікавлених сторін, а в Норвегії можуть надавати тільки спеціальні консультації.

4. Оцінка та огляд. Враховуючи той факт, що умови регіональних економік та їх поточні потреби мають тенденцію до зміни, програми структурної 
модернізації повинні також бути динамічними. Саме тому регіональна політика ЄС грунтується на оглядах досягнутого прогресу.

5. Визначення індикаторів і моніторинг. Забезпечення високого ступеня адаптивності управління процесом структурної модернізації регіональної економіки потребує постійного моніторингу змін умов зовнішнього та внутрішнього середовища, тому в країнах ЄС постійно здійснюється аналіз ефективності реалізації відповідних програм. Для

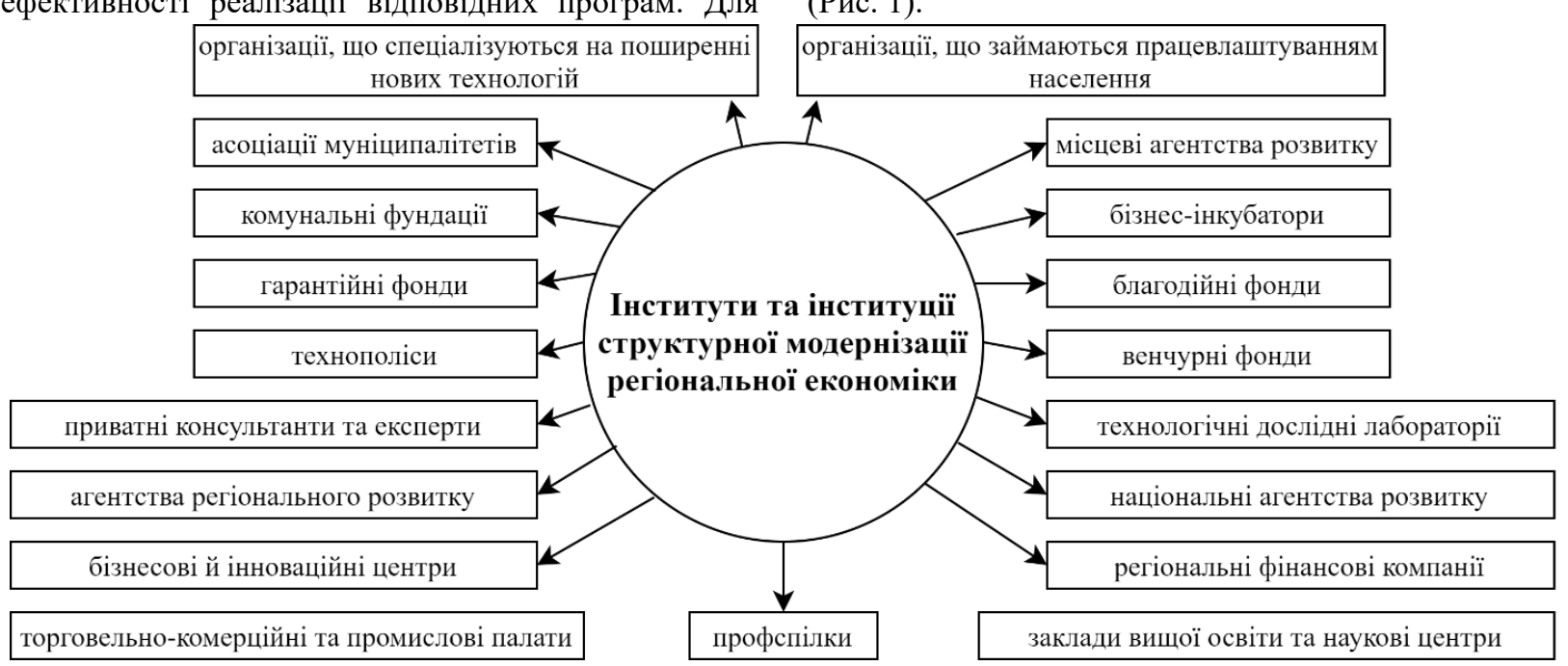

Рис. 1. Інститути та інституції структурної модернізації регіональної економіки в СС [10]

Структурна модернізація регіональної економіки являється важливим аспектом забезпечення сталого розвитку національної економіки. Особливо актуально дане питання постає в умовах інтенсивних структурних змін в галузевій структурі регіонів, які при відсутності комплексного управління можуть спричинити затяжну структурну кризу. Для оцінки структурних зрушень в регіональній економіці розраховують коефіцієнти структурних зрушень, що відображають зміну галузевої структури за основними економічними показниками регіону. Розрахуємо інтегральні коефіцієнти структурних зрушень в регіонах України у 2017 році за методом Гатаєвої (формула 1) [11]:

$$
K=\sqrt{\frac{\sum_{i=1}^{n}\left(d_{i 1}-d_{i 0}\right)^{2}}{\sum_{i=1}^{n} d_{i 1}^{2}-\sum_{i=1}^{n} d_{i 0}^{2}}}
$$

де $d_{i 1}$ - частка i-ої галузі в сумарному показнику регіону у 2017 році;

$d_{i 0}$ - частка і-ої галузі в сумарному показнику регіону у 2016 році.

Для оцінки структурних зрушень використаємо основні показники економіки регіонів, а саме: капітальні інвестиції, кількість зайнятих, валовий випуск, валова додана вартість, проміжне споживання. Результати розрахунків наведено в Таблиці 1.

Таблиця 1

Інтегральні коефіцієнти структурних зрушень за основними показниками економіки регіонів України*

\begin{tabular}{|l|c|c|c|c|c|}
\hline & $\begin{array}{c}\text { Капітальні } \\
\text { інвестиції }\end{array}$ & $\begin{array}{c}\text { Кількість } \\
\text { зайнятих }\end{array}$ & $\begin{array}{c}\text { Валовий } \\
\text { випуск }\end{array}$ & $\begin{array}{c}\text { Валова додана } \\
\text { вартість }\end{array}$ & $\begin{array}{c}\text { Проміжне } \\
\text { споживання }\end{array}$ \\
\hline Вінницька & 6,29 & 2,40 & 4,69 & 7,82 & 3,35 \\
\hline Волинська & 15,57 & 0,92 & 15,97 & 21,22 & 11,73 \\
\hline Дніпропетровська & 9,36 & 1,24 & 3,77 & 6,01 & 3,07 \\
\hline Донецька & 11,86 & 7,82 & 7,56 & 10,50 & 6,80 \\
\hline Житомирська & 16,86 & 1,33 & 3,45 & 5,51 & 2,85 \\
\hline Закарпатська & 18,53 & 1,78 & 11,22 & 9,92 & 11,33 \\
\hline Запорізька & 10,18 & 1,33 & 4,44 & 5,82 & 3,89 \\
\hline Івано-Франківська & 15,58 & 0,63 & 13,83 & 10,73 & 15,34 \\
\hline
\end{tabular}


Продовження табл. 1

\begin{tabular}{|l|c|c|c|c|c|}
\hline Київська & 14,79 & 2,17 & 3,66 & 6,37 & 2,78 \\
\hline Кіровоградська & 13,76 & 0,68 & 10,18 & 12,70 & 8,43 \\
\hline Луганська & 34,00 & 8,56 & 27,08 & 25,36 & 24,77 \\
\hline Львівська & 8,75 & 2,00 & 6,84 & 9,41 & 4,63 \\
\hline Миколаївська & 28,91 & 1,00 & 6,47 & 8,73 & 5,50 \\
\hline Одеська & 15,57 & 1,05 & 6,05 & 6,07 & 6,45 \\
\hline Полтавська & 15,11 & 1,24 & 9,20 & 10,28 & 7,89 \\
\hline Рівненська & 20,60 & 1,26 & 5,81 & 7,42 & 5,21 \\
\hline Сумська & 5,52 & 1,17 & 4,58 & 7,49 & 3,36 \\
\hline Тернопільська & 6,45 & 2,41 & 2,43 & 4,63 & 3,26 \\
\hline Харківська & 19,92 & 0,90 & 4,35 & 6,42 & 3,37 \\
\hline Херсонська & 27,28 & 1,15 & 5,06 & 7,51 & 3,70 \\
\hline Хмельницька & 16,25 & 0,82 & 4,05 & 4,79 & 4,13 \\
\hline Черкаська & 11,21 & 1,01 & 8,15 & 11,76 & 6,17 \\
\hline Чернівецька & 4,46 & 0,90 & 6,44 & 8,28 & 5,24 \\
\hline Чернігівська & 14,86 & 1,21 & 5,71 & 7,31 & 5,12 \\
\hline м. Київ & 10,01 & 2,63 & 3,36 & 2,54 & 4,31 \\
\hline
\end{tabular}

* - розраховано на основі джерел [12-14]

Розрахунки вказують на суттєві структурні зрушення (2-10\%) щодо показників капітальних інвестицій у Чернівецькій, Сумській, Вінницькій, Тернопільській, Львівській та Дніпропетровській областях. Вісімнадцять регіонів зазнали великих структурних зрушень, а в найгіршому становищі знаходиться Луганська область. Щодо кількості зайнятих, в переважній кількості регіонів спостерігаються незначні структурні зрушення (менш як $2 \%$ ), на противагу яким відмічається дисбаланс в Донецькій та Луганській областях.

Найменші зміни валового випуску зазнала Тернопільська обл., а найбільші - Кіровоградська, Закарпатська, Івано-Франківська, Волинська та Луганська області. Тим часом, за доданою вартістю відзначаються суттеві зрушення у вісімнадцяти регіонів України, а великі - у Полтавській, Донецькій, ІваноФранківській, Черкаській, Кіровоградській, Волинській та Луганській областях. Щодо проміжного споживання, то великі структурні зрушення відзначаються в Закарпатській, Волинській, ІваноФранківській та Луганській областях.

Отже, найбільших структурних зрушень зазнали Луганська, Волинська, Івано-Франківська, Закарпатська та Кіровоградська області.

Аналіз структури економіки України вказує на те, що в ній переважають III, IV i V технологічні уклади. Протягом останніх років відзначається збільшення питомої ваги третього укладу та скорочення новітніх інноваційних технологій, що $є$ несприятливим фактором на шляху переходу до постіндуст- ріальної економіки. Разом з тим, спостерігається диспропорція технологічних укладів в економіці різних регіонів, що вказує на нерівномірність технологічного розвитку [15].

Причинами наявних структурних диспропорцій в регіональній економіці України є наступні: диференціація потенціалу пристосування регіонів до сучасних вимог конкурентного середовища, відтік ресурсів та капіталу в найбільш розвинені регіони, відсутність системності структурних реформ в державі.

Для подолання зазначених проблем розвитку регіонів важливо забезпечити умови розвитку ї конкурентоспроможності. Отже, структурна політика в Україні повинна бути спрямована на збільшення частки капітальних інвестицій, зайнятості, випуску продукції, доданої вартості та проміжного споживання в галузях регіональної економіки, від яких залежить загальний розвиток регіону, а саме: добувна промисловість, переробна промисловість, високотехнологічна промисловість, сфера послуг (бізнес-послуги, послуги у сфері ІКТ), сільське господарство.

Модернізація добувної та переробної промисловості, за аналогією з європейським досвідом, повинна грунтуватися на активній співпраці $з$ науковою сферою держави, що має значний потенціал. Реструктуризація високотехнологічної промисловості повинна реалізовуватися за допомогою формування кластерів, посилення міжнародного співробітництва, державної підтримки науково-дослідної 
діяльності. Розвиток сільського господарства можливий за умови консолідації та формування холдингів, а також активізації інноваційної активності суб'єктів господарювання в регіонах. Розширення сфери послуг повинно супроводжуватися партнерством між органами влади різних рівнів, науковоосвітньою сферою та приватним сектором. Відтак, формування інституціональної моделі структурної модернізації регіональної економіки України повинно передбачати розвиток вертикальних інтегрованих структур та інститутів сприяння малому підприємництву.

\section{Висновки}

Проаналізувавши динаміку структурних змін в регіонах України, було визначено, що управлінський вплив не спрямований на впровадження технологічних та організаційних інновацій. Диспропорції в розвитку регіонів нагнітаються постійними змінами в інституціональній та правовій сферах господарської діяльності регіонів, а також наявною інституційною інерцією.

Розробка та реалізація структурних та технологічних сценаріїв модернізації регіонів України повинна здійснюватися в рамках довгострокової стратегії економічного розвитку країни, де промислова політика повинна відігравати провідну роль у вирішенні структурної асиметрії, сприянні модернізації та створенню нових високотехнологічних секторів промисловості.

\section{Література}

1. Архипенко, I. Зарубіжний досвід формування й реалізаиії регіональної економічної політики. [Текст] / I. Архипенко // Державне управління та місиеве самоврядування. 2019. вип. 2(41). C. 32-42.

2. Бородіна, О.А. Особливості формування регіональної політики в країнах СС: досвід для Украӥни. [Текст] / O.A. Бородіна // Теорія та практика державного управління. 2011. Bun. 4(35). C. 459-467.

3. Іжа, М. Трансформація регіональної політики ЄС: висновки для України. [Електронний ресурс] / М. Іжа // Теоретичні та прикладні питання державотворення. 2013. №. 12.1 Режим доступу: http://nbuv.gov.ua/UJRN/tppd_2013_12_3 (дата звернення 24.02.2020)

4. Ціватий, В.Г. Глобалізація та європейська регіональна політика: історичні імперативи і сучасність. [Текст] / В.Г. Ціватий // Науковий вісник Дипломатичної академії України. 2012. Bun. 18(спец. вип.). С. 20-26.

5. Марушевський, Г. Досвід інституцііалізації держсавного управління збалансованим розвитком у краӥнах $E C$. [Текст] / Г. Марушевський // Вісник Національної академіі державного управління при Президентові України. 2013. №. 2. C. $80-89$.

6. Максимчук, М.В. Моделювання інституиійної взаємодії державних та регіональних органів влади при модернізаиіï промислового потенціалу регіону. [Текст] / М.В. Мак- симчук // Економічні науки. Серія "Регіональна економіка». 2012. Випуск 9(35). Ч.1. С. 294-303.

7. Прокопюк, А. Регіон як категорія просторового розвитку. [Текст] / А. Прокопюк // Економіка та суспільство. 2016. Bun.5. С. 275-279.

8. Офіційний сайт Статистичного управління Європейського союзу. [Електронний ресурс] - Режим доступу: https://ec.europa.eu/info/statistics_en (дата звернення 25.02.2020)

9. Бурик, 3.М. Досвід інституиійного забезпечення регулювання сталого розвитку держав Свропейського союзу. [Текст] / 3.М. Бурик // Економічний простір. 2018. № 129. C. 5-16.

10. Ліба, Н.С. Закордонний досвід реалізаиії регіональної політики. [Текст] / Н.С. Ліба // Науковий вісник Ужгородського національного університету. 2016. №. 6 (2). С. 56-59.

11. Романова, Т.В. Інтегральні показники оцінювання структурних зрушень в економіиі. [Текст] / Т.В. Романова Економіка і регіон. 2016. № 6(61). С. 20-27.

12. Валовий регіональний продукт у 2017 рочі [Текст] : статистичний збірник / Державний комітет статистики України. Київ, 2019. 138 с.

13. Регіони Украӥни [Текст] : статистичний збірник / Державний комітет статистики України. Київ, 2019. 4.1. 309 c.

14. Регіони Украӥни [Текст] : статистичний збірник / Державний комітет статистики Украӥни. Київ, 2019. 4.2. $657 c$

15. Кириченко, О.С. Реалізація структурної політики держави та ї̈ промислового розвитку в контексті забезпечення економічної безпеки. [Текст] / О.С. Кириленко // Вчені записки Університету «КРОК». 2019. №. 2 (54). С. 102-109.

\section{References}

1. Arkhypenko, I. (2019) Zarubizhnyi dosvid formuvannia y realizatsii rehionalnoi ekonomichnoi polityky [Foreign experience in the formation and implementation of regional economic policy]. Derzhavne upravlinnia ta mistseve samovriaduvannia, vol. 2(41), pp. 32-42.

2. Borodina, O.A. (2011) Osoblyvosti formuvannia rehionalnoi polityky $\mathrm{v}$ krainakh YeS: dosvid dlia Ukrainy [Features of regional policy-making in EU countries: experience for Ukraine]. Teoriia ta praktyka derzhavnoho upravlinnia, vol. 4(35), pp. 459-467.

3. Izha, M. (2013) Transformatsiia rehionalnoi polityky YeS: vysnovky dlia Ukrainy [Transformation of EU Regional Policy: Conclusions for Ukraine]. Teoretychni ta prykladni pytannia derzhavotvorennia (electronic journal), no. 12, Available at: http://nbuv.gov.ua/UJRN/tppd_2013_12_3 (accessed 24 February 2020)

4. Tsivatyi, V.H. (2012) Hlobalizatsiia ta yevropeiska rehionalna polityka: istorychni imperatyvy i suchasnist [Globalization and European regional policy: historical imperatives and modernity]. Naukovyi visnyk Dyplomatychnoi akademii Ukrainy, vol. 18, pp. 20-26.

5. Marushevskyi, H. (2013) Dosvid instytutsializatsii derzhavnoho upravlinnia zbalansovanym rozvytkom $\mathrm{u}$ krainakh YeS [Experience of institutionalizing public administration in balanced development in EU countries]. 
Visnyk Natsionalnoi akademii derzhavnoho upravlinnia pry Prezydentovi Ukrainy, no. 2, pp. 80-89.

6. Maksymchuk, M.V. (2012) Modeliuvannia instytutsiinoi vzaiemodii derzhavnykh ta rehionalnykh orhaniv vlady pry modernizatsii promyslovoho potentsialu rehionu [Modeling of institutional interaction of state and regional authorities while modernizing the industrial potential of the region]. Ekonomichni nauky, vol. 9(35), Ch.1, pp. 294-303.

7. Prokopiuk, A. (2016) Rehion yak katehoriia prostorovoho rozvytku [Region as a category of spatial development]. Ekonomika ta suspilstvo, vol.5, pp. 275-279.

8. Official site of the Statistical Office of the European Union. Available at: https://ec.europa.eu/info/statistics_en (accessed 25 February 2020)

9. Buryk, Z.M. (2018) Dosvid instytutsiinoho zabezpechennia rehuliuvannia staloho rozvytku derzhav Yevropeiskoho soiuzu [Experience of institutional support for regulation of sustainable development of the European Union countries]. Ekonomichnyi prostir, no. 129, pp. 5-16.

10. Liba, N. S. (2016) Zakordonnyi dosvid realizatsii rehionalnoi polityky [Foreign experience in the implementation of regional policy]. Naukovyi visnyk Uzhhorodskoho natsionalnoho universytetu, no. 6 (2), pp. 56-59.

11. Romanova, T.V. (2016) Intehralni pokaznyky otsiniuvannia strukturnykh zrushen $\mathrm{v}$ ekonomitsi [Integral indicators of structural changes in the economy]. Ekonomika $i$ rehion, no. 6(61), pp. 20-27.

12. Derzhavna komitet statystyky Ukrainy (2019) Valovyi rehionalnyi produkt u 2017 rotsi [Gross regional product in 2017], Kyiv, Informatsiino-analitychne ahentstvo.
13. Derzhavna komitet statystyky Ukrainy (2019) Rehiony Ukrainy [Regions of Ukraine] P.1, Kyiv, Informatsiinoanalitychne ahentstvo.

14. Derzhavna komitet statystyky Ukrainy (2019) Rehiony Ukrainy [Regions of Ukraine] P.2, Kyiv, Informatsiinoanalitychne ahentstvo.

15. Kyrychenko, O.C. (2019) Realizatsiia strukturnoi polityky derzhavy ta yii promyslovoho rozvytku $\mathrm{v}$ konteksti zabezpechennia ekonomichnoi bezpeky [Implementation of the structural policy of the state and its industrial development in the context of ensuring economic security]. Vcheni zapysky Universytetu «KROK», no.2 (54), pp. 102-109.

Рецензент: доктор економічних наук, професор кафедри міжнародних економічних відносин та європейської інтеграції В.С. Данкевич, Житомирський національний агроекологічнй університет, Житомир, Україна

\section{Автор: ШАШИНА Марина Володимирівна} кандидат економічних наук, доцент кафедри економіки і підприємництва

Національний технічний університет Украйни «Киїський політехнічний інститут імені Ігоря Сікорського»

E-mail-1604102018@ukr.net

\title{
FORMATION OF THE EUROPEAN INSTITUTIONAL MODEL OF THE REGIONAL ECONOMY STRUCTURAL MODERNIZATION
}

Or Igor Sikorsky Kyiv Polytechnic Institute, Ukraine

\author{
M. Shashyna
}

Within the EU countries, an effective institutional model has been created to ensure structural regional modernization of the economy, which applies not only to all hierarchical levels of government, but also to nongovernmental organizations. This system makes it possible to implement the principles of sustainable development of the outermost regions, as it is quite dense and detailed. The current realities of regional development of Ukraine's regions, their disproportion and asymmetry raise the necessity for a thorough structural adjustment, the realization of which is impossible without analyzing the best practices of the world in the implementation of economic and structural regional policies.

The purpose of the article is to study the practical aspects of formation of the European institutional model of regional economy structural modernization.

The article substantiates the essence of the concept of "structural modernization of the regional economy". The historical process of forming the institutional model of the regional economy structural modernization in Europe is revealed. The principles of building the European model of structural modernization are revealed, namely: leadership and horizontal coordination, vertical coordination, stakeholder involvement, evaluation and review, definition of indicators and monitoring. The main institutions contributing to the structural modernization of European regions have been identified. The integral coefficients of structural shifts in the regions of Ukraine in 2017 were calculated and the regions that underwent the largest structural changes were identified. The main causes of structural imbalances in the regional economy of Ukraine are outlined.

The priorities of regional structural policy institutionalization should be the mechanisms of contradictions overcoming and interests harmonization at distribution and use of regional development potential, formation of normative-legal support of structural transformations in economy of regions, development and implementation of measures for attracting investors in the economic sectors of the regions, which can be the drivers of transformational changes (mining and processing industry, high-tech industry, services, agriculture). It is proposed to form an institutional model of regional economy structural modernization of Ukraine on the basis of vertical integrated structures and institutions for promoting small business.

Keywords: structural modernization, regional policy, institutional model, EU, structural changes. 